\author{
А. Чайковська, \\ кандидат юридичних наук, \\ адвокат \\ Адвокатського об’єднання «Борзих та партнери»
}

\title{
ОСОБЛИВОСТІ НАДАННЯ ПРОЕКТНО-КОШТОРИСНОЇ ДОКУМЕНТАЦІЇ ЗА ЗАПИТАМИ НА ІНФОРМАЦІЮ В АСПЕКТІ ЗАХИСТУ ПРАВ НА КОМЕРЦІЙНУ ТАЕМНИЦЮ
}

Постановка проблеми. Законодавством України гарантується право на доступ до публічної інформації, який забезпечується, зокрема, шляхом іiї надання за запитами на інформацію в порядку Закону України «Про доступ до публічної інформації». Водночас законодавством регулюється як перелік інформації, до якої не може бути обмежено доступ, так і інформація з обмеженим доступом. Одним із дискусійних постає питання щодо підстав надання проектно-кошторисної документації за запитами на інформацію, поданими в порядку Закону України «Про доступ до публічної інформації, в аспекті як гарантованого доступу до публічної інформації, так i, водночас, необхідності здійснення захисту комерційної таємниці виконавця робіт, яка міститься в проектно-кошторисній документації.

Метою статті $€$ аналіз особливостей надання проектно-кошторисної документації, яка містить комерційну таємницю виконавця робіт, за запитами на інформацію, поданими в порядку Закону України «Про доступ до публічної інформації».

Виклад основного матеріалу. За змістом статті 19 Закону України «Про доступ до публічної інформаціiі» запит на інформацію - це прохання особи до розпорядника інформації надати публічну інформацію, що знаходиться у його володінні. Названим законом визначається перелік інформації, до якої не може бути обмежено доступ. Так, згідно із частиною 5 статті 6 Закону України «Про доступ до публічної інформації, не може бути обмежено доступ до інформації про складання, розгляд і затвердження бюджетів, кошторисів розпорядників бюджетних коштів та плани використання бюджетних коштів одержувачів бюджетних коштів, а також їх виконання за розписами, бюджетними програмами та видатками тощо [9].

Разом із цим Законом України «Про доступ до публічної інформації» регулюється інформація 3 обмеженим доступом, зокрема конфіденційна інформація, якою є інформація, доступ до якої обмежено фізичною або юридичною особою, крім суб'єктів владних повноважень, та яка може поширюватися у визначеному ними порядку за їхнім бажанням відповідно до передбачених ними умов. Розпорядники інформації, які володіють конфіденційною інформацією, можуть поширювати іiі лише за згодою осіб, які обмежили доступ до інформації, а за відсутності такої згоди - лише в інтересах національної безпеки, економічного добробуту та прав людини. Відповідно до частини 1 статті 22 Законом України «Про доступ до публічної інформації» розпорядник інформації має право відмовити в задоволенні запиту, зокрема, у випадку, якщо інформація, 
що запитується, належить до категоpiï інформації з обмеженим доступом [9]. До кола конфіденційної інформації у сфері господарської (підприємницької) діяльності відноситься, зокрема, комерційна таємниця [8].

Відповідно до статті 505 Цивільного кодексу України комерційною таємницею $є$ інформація, яка $є$ секретною в тому розумінні, що вона в цілому чи в певній формі та сукупності їі складових частин є невідомою та не $є$ легкодоступною для осіб, які звичайно мають справу 3 видом інформації, до якого вона належить, у зв'язку із цим має комерційну цінність та була предметом адекватних існуючим обставинам заходів щодо збереження iii секретності, вжитих особою, яка законно контролює цю інформацію. До майнових прав інтелектуальної власності на комерційну таємницю належить, зокрема, виключне право перешкоджати неправомірному розголошенню, збиранню або використанню комерційної таємниці [12].

Законодавством визначені механізми охорони і захисту комерційної таємниці. Відповідно до частини 1 статті 162 Господарського кодексу України суб’єкт господарювання, що $є$ володільцем технічної, організаційної або іншої комерційної інформації, має право на захист від незаконного використання цієї інформації третіми особами, за умов, що ця інформація має комерційну цінність у зв'язку з тим, що вона невідома третім особам і до неї немає вільного доступу інших осіб на законних підставах, а володілець інформації вживає належних заходів до охорони іiі конфіденційності [1]. Крім того, законодавством встановлена відповідальність за незаконне збирання з метою використання або використання відомостей, що становлять комерційну таємницю та їх розголошення [2].

В аспекті захисту прав на комерційну таємницю особливо актуальним постає питання про підстави надання проектно-кошторисної доку- ментації за запитами на інформацію, поданими в порядку Закону України «Про доступ до публічної інформації». Поширеною практикою є звернення із запитами на інформацію, в порядку Закону України «Про доступ до публічної інформації, до розпорядників інформації про надання копій проектно-кошторисної документації. Водночас проектно-кошторисна документація може містити інформацію, яка становить комерційну таємницю виконавця робіт.

Відповідно до судової справи № 730/145/15-а фізична особа звернулась до Борзнянського районного суду Чернігівської області 3 позовом до відділу освіти про визнання протиправним рішення про відмову у задоволенні запиту на інформацію та покладенням обов`язку розглянути запити фізичної особи на підставі Закону України «Про доступ до публічної інформації» 3 наданням копій проектно-кошторисної документації з ремонту приміщень у школах. В обгрунтування адміністративного позову фізична особа посилалась на те, що вона звернулась до відділу освіти 3 запитами про надання ій особисто інформації, що стосується проектно-кошторисної документації з ремонту приміщень шкіл. Однак відділ освіти відповів письмовою відмовою у наданні запитуваної інформації, обгрунтовуючи це тим, що проектно-кошторисна документація має обмежений доступ, тому що $є$ власністю виконавця робіт, відомості становлять комерційну таємницю i не можуть бути оприлюднені відділом освіти. На думку відповідача, інформація, що міститься в проектно-кошторисній документації, прямо пов'язана і з діяльністю підрядника. Крім того, виконавець робіт в своїй заяві на ім'я начальника відділу освіти Борзнянської районної державної адміністрації заперечив проти оприлюднення інформації щодо робіт з ремонту в приміщеннях шкіл. Натомість позивач вважає безпідставним 
віднесення відповідачем запитуваної інформації до комерційної таємниці, оскільки виконання робіт, передбачене проектно-кошторисною документацією, здійснено за рахунок державних коштів та ця інформація $є$ публічною, оскільки була створена в процесі виконання суб'єктом владних повноважень своїх обов'язків.

Відповідно до постанови Борзнянського районного суду Чернігівської області від 24 лютого 2015 року у справі № $730 / 145 / 15$-а в адміністративному позові було відмовлено у повному обсязі [3]. Відмовляючи в задоволенні позовних вимог, суд першої інстанції виходив $з$ того, що запитувана позивачем у відповідача проектно-кошторисна документація $€$ комерційною таємницею виконавця ремонтних робіт і має обмежений доступ.

Київський апеляційний адміністративний суд постановою від 22 квітня 2015 року апеляційну скаргу фізичної особи задовольнив частково [6]. Апеляційний суд визнав протиправними діï відділу освіти щодо несвоєчасного надання відповіді на запити фізичної особи, однак у задоволенні адміністративного позову в іншій частині позовних вимог (визнання протиправним рішення про відмову у задоволенні запиту) було відмовлено. Колегія суддів апеляційної інстанції звернула увагу, що проектно-кошторисна документація безпосередньо стосується комерційної діяльності виконавця робіт - суб'єкта господарювання i становить його комерційну таємницю. Суд апеляційної інстанції у даній справі встановив, що позивач у своїх запитах просила відповідача надати їй не просто окремі відомості щодо витрачання бюджетних коштів, а саме копії проектно-кошторисної документації з ремонту приміщень відповідних шкіл із зазначенням відомостей про виконані роботи і витрачені на це кошти, тобто конкретні документи, які безпосередньо стосуються комерційної діяльності виконавця таких ремонтних робіт і не можуть бути надані позивачу без його згоди.
Відповідно до постанови Верховного Суду від 26 жовтня 2018 року касаційну скаргу фізичної особи було залишено без задоволення, a постанову Київського апеляційного адміністративного суду від 22 квітня 2015 року було залишено без змін [5]. Суд касаційної інстанції визначив, що інформація, яка становить комерційну таємницю щодо діяльності суб'єкта господарювання, не належить до публічної інформації 3 вільним доступом та не підлягає розголошенню без згоди такого суб'єкта господарювання. Таким чином й документи, які містять інформацію, що становить комерційну таємницю, не можуть бути надані органом влади без отримання відповідної згоди від суб'єкта господарювання, у межах комерційної діяльності якого вони були створені.

Однак не можна говорити про сталу судову практику у наведеній категорії справ. Так, відповідно до постанови від 30 жовтня 2015 року у справі № 825/3360/15-а Чернігівським окружним адміністративним судом, було розглянуто справу за адміністративним позовом фізичної особи до відділу освіти про визнання протиправними дій відповідача у зв'язку з безпідставною відмовою в задоволенні запиту на інформацію в частині ненадання копій проектно-кошторисної документації та акта виконаних робіт [7]. Свої вимоги позивач обгрунтовував тим, що не може бути обмежено доступ до інформації про розпорядження бюджетними коштами, володіння, користування чи розпорядження державним, комунальним майном, у тому числі до копій відповідних документів, умови отримання цих коштів чи майна, прізвища, імена, по батькові фізичних осіб та найменування юридичних осіб, які отримали ці кошти або майно. Відповідно до позиції відповідача у справі, надати копії проектно-кошторисної документації та акти виконаних робіт відповідач не може, оскільки інформація, яка 
міститься у вказаних документах, відноситься до інформації з обмеженим доступом, оскільки $€$ комерційною таємницею підрядника. Розголошення інформації про проектно-кошторисну документацію та про акт виконаних робіт, може завдати реальної та істотної шкоди, оскільки вона прямо стосується комерційної діяльності виконавця робіт, розповсюдження такої інформації може негативно вплинути на господарську діяльність підрядника, а також може бути використана проти нього з метою недобросовісної конкуренції. Крім того, підрядник, з яким було укладено проектно-кошторисну документацію та акт, надіслав заяву, в якій заперечував проти оприлюднення інформації щодо ремонтних робіт у вказаному навчальному закладі. Крім того, між підрядником та начальником відділу освіти було підписано зобов'язання про нерозголошення таємниці, оскільки у діяльності виконавця робіт запроваджено режим комерційної таємниці.

Суд першої інстанції зробив висновок, що проектно-кошторисна документація, становить комерційну таємницю щодо діяльності суб'єкта господарювання фізичної особипідприємця підрядника, оскільки в своїй сукупності безпосередньо стосується комерційної діяльності виконавця робіт. Постанову Чернігівського окружного адміністративного суду від 30 жовтня 2015 року у справі № 825/3360/15-а залишено без змін ухвалою від 09 лютого 2016 року Київського апеляційного адміністративного суду [11]. Однак, відповідно до постанови Верховного Суду від 18 липня 2018 року у справі № 825/3360/15-а касаційну скаргу фізичної особи було задоволено частково [4]. Постанову Чернігівського окружного адміністративного суду від 30 жовтня 2015 року та ухвалу Київського апеляційного адміністративного суду від 9 лютого 2016 року в частині відмови у задоволенні позовних вимог щодо ненадання копій проектно-кошторисної документації було скасовано, справу в цій частині направлено на новий розгляд до суду першої інстанції.

Судом касаційної інстанції під час прийняття рішення було зауважено, що майнові права інтелектуальної власності на комерційну таємницю, до якої може належати проектно-кошторисна документація виконавця робіт, належатимуть останній, як виключне право інтелектуальної власності. Відповідно, правовідносини, що склалися між сторонами, можуть впливати на виключне право інтелектуальної власності виконавця робіт, але за умови, що суди дійдуть висновку про приналежність проектно-кошторисної документації до комерційної таємниці. Суд касаційної інстанції зауважив, що, розглядаючи справу по суті, суди першої та апеляційної інстанцій не вжили жодних заходів щодо з'ясування даних про те, яка інформація дійсно міститься у проектно-кошторисній документації і чи може така інформація вважатися інформацією з обмеженим доступом. Крім того, суди першої та апеляційної інстанції без залучення третьої особи до участі у справі вирішили питання щодо забезпечення права останньої на збереження комерційної таємниці. Матеріали справи містять клопотання представника позивача про витребування проектно-кошторисної документації та дослідження іï у закритому судовому засіданні з метою нерозголошення охоронюваної законом таємниці. Проте судом апеляційної інстанціi таку заяву не було розглянуто, що призвело до неповного з'ясування обставин справи. Таким чином, суд касаційної інстанції встановив, що суди попередніх інстанцій не дослідили, чи являється обмеження у доступі до запитуваної позивачем інформації виправданим та таким, що відповідає критеріям, встановленим законодавством. Ураховуючи викладене, колегія суддів Верховного Суду вважає, що в даній справі порушення 
судами попередніх інстанцій норм процесуального права унеможливлює встановлення об’єктивної істини, оскільки суди не встановили фактичні обставини, що мають значення для правильного вирішення справи в повному обсязі.

У подальшому у справі № 825/3360/15-а рішенням від 17 жовтня 2018 року Чернігівського окружного адміністративного суду позов фізичної особи було задоволено та визнано протиправними дії щодо ненадання фізичній особі запитуваної інформації про проектно-кошторисну документацію та вирішено зобов'язати надати запитувану інформацію, а саме: копію проектно-кошторисної документації [10]. Суд обгрунтував своє рішення тим, що на підставі аналізу норм права не підлягає обмеженню в наданні за запитом про публічну інформацію інформація про проектно-кошторисну документацію. Як встановлено судом, позивач у своєму запиті просив відповідача надати, зокрема, копію проектно-кошторисної документації, тобто інформацію про будівельні роботи, ціну робіт за якою були використані бюджетні кошти, прозоре використання яких становить суспільний інтерес. Посилання відповідача на те, що проектно-кошторисна документація містить конфіденційну інформацію, яку неможливо поширювати без згоди особи, яка обмежила доступ до інформації, судом не були прийняті до уваги, оскільки якщо у проектно-кошторисній документації міститься інша інформація, яка має ознаки конфіденційної, то при наданні копії вказаного документу вона підлягає вилученню у спосіб, який унеможливлює іï з'ясування. Таким чином, діï відповідача щодо ненадання копії запитуваного документа були визнані протиправними та такими, що порушують права позивача на доступ до публічної інформації. 3 урахуванням зазначеного, 3 метою повного захисту прав, свобод, інтересів позивача, суд задовольнив позовні вимоги шляхом визнання протиправними дій відповідача щодо ненадання позивачу запитуваної інформації про проектно-кошторисну документацію та зобов'язав відповідача розглянути запит позивача з дотриманням вимог Закону України «Про доступ до публічної інформації» та надати запитувану інформацію, а саме: копію проектно-кошторисної документації.

Висновки. На підставі проведеного дослідження можливо дійти висновку про зміну судової практики щодо вирішення справ про оскарження рішень про відмову у наданні проектно-кошторисної документації за запитами на інформацію, поданими в порядку передбаченому Законом України «Про доступ до публічної інформації. Важливим у розгляді справи про оскарження рішень розпорядників інформації про відмову у іï наданні є дослідження такої інформації судом для з'ясування даних про те, яка інформація дійсно міститься у проектно-кошторисній документації і чи може така інформація вважатися інформацією з обмеженим доступом. Крім того, під час розгляду справ про надання проектно-кошторисної документації за запитами на інформацію вбачається за доцільне залучення виконавця робіт в якості третьої особи, до розгляду судової справи.

Аналіз судової практики дозволяє дійти також висновку, що у випадку надходження запиту про надання документів, в яких міститься комерційна таємниця, розпоряднику інформації слід виходити з того, що обмеженню доступу підлягає інформація, а не документ. Якщо документ містить інформацію з обмеженим доступом, для ознайомлення надається інформація, доступ до якої необмежений. Таким чином, у випадку наявності у запитуваному документі комерційної таємниці, вона має бути вилучена з документа, у спосіб, який унеможливлює іï з'ясування, та документ підлягає наданню за виключенням такої інформації. 
У статті досліджені особливості надання проектно-кошторисної документації, яка містить комериійну таємницю, за запитами на інформацію, поданими в порядку Закону України «Про доступ до публічної інформації. Наведено нормативно-правовий аналіз підстав надання проектно-кошторисної документації, яка містить комериійну таємницю, за запитами на інформацію. Проведено аналіз судової практики у справах про оскарження відмови в задоволенні запиту на інформацію в частині ненадання копій проектно-кошторисної документациї ma зобов'язання розглянути запит із дотриманням Закону України «Про доступ до публічної інформациї̈ $i$ надати запитувану інформацію.

У результаті проведеного дослідження виявлена наявність неоднакової судової практики під час вирішення справ про оскарження відмови в задоволенні запиту на інформацію в частині ненадання копій проектно-кошторисної документаціi. Зроблені висновки про необхідність під час розгляду справ про оскарження рішень розпорядників інформаціі про відмову у $і ̈$ наданні, в порядку, передбаченому Законом України «Про доступ до публічної інформації, досліджувати таку інформацію в судовому засіданні, для з'ясування даних про те, яка інформація дійсно міститься у проектно-кошторисній документації $i$ чи може така інформація вважатися інформацією з обмеженим доступом.

Крім того, визначено, що у випадку надходження запиту, поданого в порядку Закону України "Про доступ до публічної інформациї», про надання документів, в яких міститься комериійна таємниця, розпоряднику інформації слід виходити з того, що обмеженню доступу підлягає інформація, а не документ. Якщо документ містить інформацію з обмеженим доступом, для ознайомлення надається інформація, доступ до якої необмежений. Комерціина інформація має бути вилучена з документа, у спосіб, який унеможливлюе ї з'ясування, та документ підлягає наданню за виключенням такої інформації.

Ключові слова: комерційна таємниця, проектно-кошторисна документація, доступ до публічної інформації, запити на інформацію, конфіденційна інформація.

Chaykovska A. Peculiarities of providing design and estimate documentation for requests for information in the aspect of protection of trade secret rights

The article examines the features of providing design and estimate documentation, which contains a trade secret, upon requests for information submitted in accordance with the Law of Ukraine "About access to public information». The normative-legal analysis of the bases of providing design and estimate documentation is given, which contains a trade secret, upon request for information. Analysis of case law in cases of appeal against the refusal to satisfy a request for information, in terms of failure to provide copies of design and estimate documentation, and the obligation to consider the request in compliance with the Law of Ukraine "About access to public information" and provide the requested information was conducted.

As a result of the conducted research the existence of unequal judicial practice at the decision of cases on the appeal of refusal in satisfaction of the request for information concerning the failure to provide copies of the design and estimate documentation is revealed. It is concluded that when considering cases of appealing the decisions of information managers on the refusal to provide information in the manner prescribed by the 
Law of Ukraine "About access to public information», it is necessary to investigate such information in court, to find out what information is actually contained in the design and estimate documentation and whether such information can be considered as restricted information.

In addition, it is determined that in case of receipt of a request submitted in accordance with the Law of Ukraine "About access to public information», on the provision of documents containing a trade secret, the information manager should assume that the information is restricted, not the document. If the document contains restricted information, to review available information to which access is limited. Commercial information must be removed from the document in a way that makes it impossible to clarify it, and the document must be provided except for such information.

Key words: trade secret, design and estimate documentation, access to public information, requests for information, confidential information.

\section{Література}

1. Господарський кодекс України : Закон України від 16 січня 2003 року № 436-IV. URL: https: / / zakon.rada.gov.ua/ laws / show /436-15\#Text.

2. Кримінальний кодекс України : Закон України від 5 квітня 2001 року № 2341-III. URL: https: / / zakon.rada.gov.ua/ laws / show / 2341-14 / print.

3. Постанова Борзнянського районного суду Чернігівської області від 24 лютого 2015 року у справі
№ $730 / 145 / 15-a$. URL: https: / / reyestr.court.gov.ua / Review / 47867070 .

4. Постанова Верховного Cуду від 18 липня 2018 року у справі № 825/3360/15-a. URL: https:// reyestr.court.gov.ua / Review / 75454010 .

5. Постанова Верховного Cуду від 26 жовтня 2018 року у справі № $730 / 145 / 15-a$. URL: https: / / reyestr.court.gov.ua/Review/77417085.

6. Постанова Київського апеляційного адміністративного суду від 22 квітня 2015 року у справі № 730/145/15-a. URL: $\quad$ https://reyestr.court.gov.ua/ Review/43760526.

7. Постанова Чернігівського окружного адміністративного суду від 30 жовтня 2015 року у справі № 825/3360/15-a. URL: https: / / reyestr.court.gov.ua/Review/ 53241487.

8. Про деякі питання практики застосування господарськими судами законодавства про інформацію: інформаційний лист Вищого господарського суду України від 28.03.2007 N 01-8/184. URL: https://zakon.rada.gov.ua/laws / show / v_184600-07\#Text.

9. Про доступ до публічної інформації: Закон України від 13 січня 2011 року № 2939-VI. URL: https: / / zakon.rada.gov.ua/ laws / show / 2939-17 / print.

10. Рішення Чернігівського окружного адміністративного суду від 17 жовтня 2018 року у справі № 825/3360/15-a. URL: https: / / reyestr.court.gov.ua/Review/ 77192233.

11. Ухвала Київського апеляційного адміністративного суду від 09 лютого 2016 року у справі № 825/3360/15-a. URL: https:// reyestr.court.gov.ua/Review/ 55837310 .

12. Цивільний кодекс України: Закон України від 16 січня 2003 року № 435-IV. URL: https: / / zakon.rada.gov.ua/laws / show /435-15\#Text. 